\title{
High Reusability of Lipase Immobilised on Eggshells for Butyl Butyrate Synthesis under Optimum Condition
}

\author{
N.A. Serri ${ }^{*}$ and L.S. Mooi ${ }^{1}$ \\ ${ }^{1}$ Bioprocess Technology, School of Industrial Technology, Universiti Sains Malaysia
}

\begin{abstract}
Eggshells capacity as supporting material for immobilisation of Candida rugosa Type VII lipase (CRL) was tested. Different parameters for the immobilisation of eggshells were studied including the temperature $\left(30-50^{\circ} \mathrm{C}\right), \mathrm{pH}$ of buffer the solution $\left(\mathrm{pH}^{5}-8\right)$, particle size of the eggshells ( $\leq 1 \mathrm{~mm}, 1-2 \mathrm{~mm}$ and 2-4mm), immobilisation time (1-4 hr) and glutaraldehyde concentration (0.30$3.00 \%, \mathrm{v} / \mathrm{v})$. The best immobilisation conditions obtained were $\leq 1 \mathrm{~mm}$ size of the eggshells added with $0.75 \%$ of glutaraldehyde at $\mathrm{pH}$ buffer 6 . The immobilisation time taken was $3 \mathrm{hr}$ at $50^{\circ} \mathrm{C}$. Then optimal conditions for the ester synthesis of butyl butyrate were achieved using $2.0 \mathrm{og}$ of the immobilised lipase loading that reacted at $30^{\circ} \mathrm{C}$ using a 0.2 molar ratio of the substrate for $3 \mathrm{hr}$. Under optimal conditions (immobilization and esterification), 93.3\% of conversion yield of butyl butyrate was obtained. Furthermore, the synthesized immobilised CRL lipase demonstrate that it was highly reusable as it retained $50 \%$ of the initial activity after 31 cycles.
\end{abstract}

Keywords: lipase reusability; butyl butyrate; eggshells; immobilised

\section{INTRODUCTION}

Esters are mostly obtained from natural sources such as plant materials extraction that is costly for commercial use (Yahya et al., 1998). The use of homogenous acids as catalysts in esterification can cause the corrosion of equipment, possible hazards of handling corrosive acids as well as low yields (Bezbradica et al., 2006). Enzymatic synthesis, such as using lipase to produce ester is an attractive alternative way to reduce energy consumption (Saponjic et al., 2010). Butyl butyrate, which has a pleasant aroma, similar to pineapple, is the esters of short chain fatty acids and alcohols. This ester is widely used in the beverage, food and pharmaceutical industries. (Santos and de Castro, 2006). The optimisation of butyl butyrate synthesis catalysed using Thermomyces lanuginosus lipase (TLL) in n-hexane by Martins et al. (2013b) produced 90\% of the esterification yield and was able to retain $85 \%$ of its activity after being used for five times. Martins et al. (2013a) reported that the synthesis of butyl butyrate had improved by 2 folds with 3 folds of enzyme activity using the immobilised TLL on the styrene-divinylbenzene beads compared to the commercial Lipozyme TL-IM.

The immobilisation technology serves significant benefits compared to free enzymes. Immobilised enzymes probably reduced the cost of the process by improving the enzyme's stability, reusability plus the fact that they can easily be separated from the product with better operation control (Chattopadhyay and Sen, 2012). It is profitable for commercial development in various industries, including healthcare and medicine, food technology, agriculture, pollution recovery, fuel and energy production (Doaa and Wafaa, 2009). Lipase is widely applied in a variety of industries such as pharmaceuticals, pesticides, cosmetics, and detergents (Pandey et al., 1999). Lipase can withstand high temperature, has a wide range of $\mathrm{pH}$, easy to handle and can be repeatedly used. Lipases are widely use in esterification, transesterification, aminolysis, oximolysis, thiotransesterfication and ammoniolysis in anhydrous organic solvents (Chang et al., 2007).

A variety of carriers such as soluble dextrans, epoxy resins, chitosan, silica, and alginate can be used as support to immobilise lipases. Lipase can be immobilised on the

*Corresponding author's e-mail: aziah_serri@usm.my 
support by adsorption, cross-linking, covalent binding and encapsulation method (Jesionowski et al., 2014). Selection for both the support and immobilisation method must be considered because it will influence the enzyme activity (Mohamad et al., 2015). The immobilisation of CRL on the chitosan beads using binary immobilisation was studied by Ting et al. (2006); it gave a better thermal and $\mathrm{pH}$ stability of the immobilised lipase compared to the free lipase. This was asserted by Wu et al. (2012) in their investigation of CRL immobilised on the vesicular silica by absorption, resulting in better reusability and capability to withstand higher $\mathrm{pH}$ as well as temperature indicating improved in heat stability compare to the free CRL. On the other hand, Nasratun et al. (2009) reported that free lipase produced a higher yield in transesterification compared to the CRL immobilised on the porous bead of chitosan using physical absorption. Nonetheless, the immobilised lipase was still preferred to carry out a reaction because the end product can be easily separate and have better reusability.

The carrier limits the commercialisation of the immobilised enzyme because of the high cost of production. On the other hand, eggshell which is a waste material can be easily obtained at almost no cost (Makkar and Sharma 1983) and consequently, act as a cheaper carrier for the immobilisation of enzymes. The disposal of eggshells resulted in the high cost of waste disposal, bad smell, flies and abrasiveness (Glatz and Zhihong). In 2011, Malaysians consumed about 20 million eggs per day, and on an average, 320 eggs are consumed per person per year. Only 250 eggs are consumed per person per year in the United States and 48 eggs per person per year in India (Lee, 2011). The eggshell represents almost $11 \%$ of the total weight of the eggs, and they are commonly disposed of in landfills (Wu et al., 2013). Reusing waste eggshells as the support material for the immobilisation of lipases is one of the ways to overcome the problem.

Moreover, the eggshells possess good mechanical strength, and they are resistant to microbial attack (Makkar and Sharma, 1983). Vemuri et al. (1998) claimed that lipase from Pseudomonas sp. immobilised eggshells resulted in a more efficient biocatalyst compared to alginate beads using adsorption and entrapment methods. It shows higher lipase activity in a single factor testing of $\mathrm{pH}$ and temperature. Thus, the present study determines the best conditions for immobilising lipase via crosslinking method on eggshells at the same time optimising the synthesis of butyl butyrate ester plus the reusability testing of the catalyst.

\section{MATERIALS AND METHOD}

\section{A. Materials}

Chicken eggshells were collected from the hawker stall located at Desasiswa Bakti Permai, Universiti Sains Malaysia. Lipase (CRL) from C. rugosa Type VII with a specific lipolytic activity of $\geq 700 u n i t / m g$ solid was purchased from Sigma-Aldrich (United States of America) and used without any purification.

\section{B. Pre-treatment of Eggshells}

Eggshells were rinsed three times with distilled water and boiled. A total of $500 \mathrm{~g}$ of eggshells was boiled in 1000mL of (o.1\%) sodium dodecyl sulfate (SDS) solution for 15 minutes (Vemuri et al., 1998). The eggshells were then rinsed with distilled water to remove the residual SDS solution followed by acetone to remove the excess water. Then, the shells were dried at $60^{\circ} \mathrm{C}$ for $5 \mathrm{hr}$. The dried shells were ground to smaller pieces. The ground eggshells were then sieved through the 1.omm, 2.0mm and 4.0mm meshes.

\section{Lipase Immobilisation on Eggshells}

The CRL was immobilised on the eggshells by a crosslinking method using glutaraldehyde. A $0.75 \%$ glutaraldehyde solution (v/v) was prepared using potassium phosphate buffer (50mM, pH 7). The immobilisation was done by adding $1 \mathrm{~g}$ of eggshells, $5 \mathrm{mg}$ lipase and $10 \mathrm{~mL}$ of $0.75 \%$ glutaraldehyde solution (v/v) in $15 \mathrm{~mL}$ stopped conical flask. The mixture was shaken for $1 \mathrm{hr}$ at $15 \mathrm{orpm}$ and $30^{\circ} \mathrm{C}$. Afterwards, the eggshells were filtered and washed with potassium phosphate buffer to remove excess glutaraldehyde and lipases. The immobilised enzyme was kept in the freezer until for later use.

\section{Synthesis of Butyl butyrate}

A mixture of n-butanol and butyric acid with 1:1 molar ratio (10ml) added with one gram of immobilised CRL to initiate esterification reaction. The reaction solution was kept in a 
stoppered conical flask and incubated in an orbital shaker (150rpm) at $30^{\circ} \mathrm{C}$ for $1 \mathrm{hr}$. A control sample was performed by mixing the substrate in a conical flask without the immobilised lipases and incubated under the same condition. $1 \mathrm{~mL}$ reaction sample and control were directly titrated with $0.4 \mathrm{M}$ of sodium hydroxide solution by adding phenolphthalein as an indicator. The volume of sodium hydroxide solution being used in the titration was substituted as in Eq. 1:

Conversion yield $(\%)=\frac{\operatorname{Vol~NaOH}(\mathrm{w} / \mathrm{o} \mathrm{E})-\mathrm{Vol} \mathrm{NaOH}(\text { with E })}{\operatorname{Vol~NaOH}(\mathrm{w} / \mathrm{o} \mathrm{E})} \times 100 \%$

Where:

Vol $\mathrm{NaOH}(\mathrm{w} / \mathrm{o} \mathrm{E})$ = Volume of sodium hydroxide without enzyme

Vol $\mathrm{NaOH}$ (with E) = Volume of sodium hydroxide with enzyme

The effects of the parameters such as the reaction time (1-7 $\mathrm{hr}$ ), temperature $\left(30-60^{\circ} \mathrm{C}\right)$, the molar ratio of butyric acid: butanol (0.2-1.8), and eggshells loading (0.1- 4.og) on the esterification reaction were investigated.

\section{Scanning electron microscopy (SEM)}

Analysis of the eggshells before and after the immobilisation process and after the esterification reaction was conducted using a scanning electron microscope (SEM EVO MA 10/EDX). All the samples were sputter-coated with gold and placed in a chamber. Micrographs were obtained using a scanning electron microscope (SEM).

\section{RESULTS AND DISCUSSION}

\section{A. Effect of Different Parameters on the Immobilisation Process}

\section{Effect of temperature}

Temperature plays a vital role in the immobilisation of lipase on eggshells. The best immobilisation temperature was determined by incubating the reaction mixture in the range of $30^{\circ} \mathrm{C}$ to $60^{\circ} \mathrm{C}$ (Figure 1). The esterification yield increases from $56.67 \%$ at $30^{\circ} \mathrm{C}$ to $65.56 \%$ at $50^{\circ} \mathrm{C}$. Then, the butyl butyrate conversion slightly decreases at $60^{\circ} \mathrm{C}$. The highest esterification yield was $65.56 \%$ at $50^{\circ} \mathrm{C}$, which indicates that the lipase immobilised on the eggshells requires greater kinetic energy to deactivate. High temperature $\left(60^{\circ} \mathrm{C}\right)$ causes changes in the active site and reduces the activity of the lipase ( $56.67 \%$ conversion). According to Spinelli et al. (2014), the immobilised CRL shows maximum activity at a temperature between $55^{\circ} \mathrm{C}$ to $60^{\circ} \mathrm{C}$. Higher temperature denatures the lipase, and at a lower temperature, the catalyst will be inactivated.

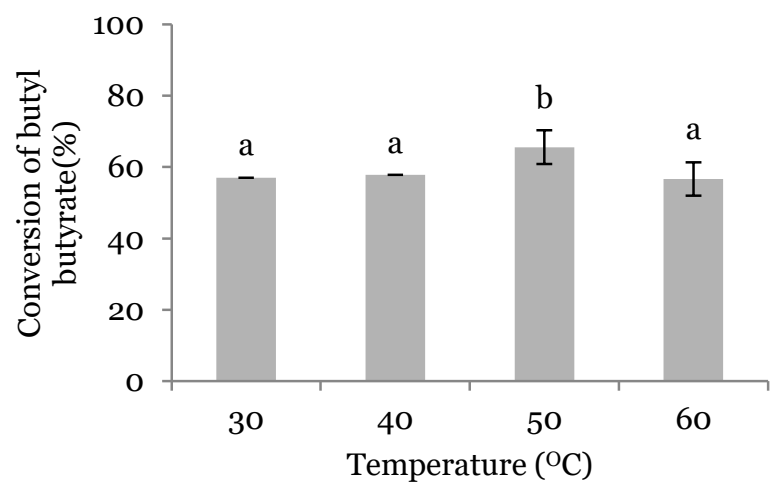

Figure 1. Esterification yield at different immobilisation temperature

*Data expressed as mean of duplicate \pm error value *a, b, subsets in Tukey HSD test for alpha $=0.05$

\section{Effect of $p H$ buffer solution}

$\mathrm{pH}$ is also a factor for the stability of enzymes where extremely high or low in pH can result in decreasing enzyme activity. As seen in Figure 2, the pH of the buffer solution (58) has a significant effect on immobilisation and esterification yield of the immobilised CRL. The esterification yield increases when the $\mathrm{pH}$ of the buffer solution increases from pH 5 (58.89\%) to $\mathrm{pH} 6$ (61.85\%). Higher than $\mathrm{pH}$ 6, the esterification yields gradually decreases to $55.93 \%$ at $\mathrm{pH}$ 8. Therefore, buffer $\mathrm{pH} 6$ is the optimal $\mathrm{pH}$ to immobilise CRL on eggshells as the esterification yield reaches the maximum (61.85\%). The properties of the carrier may influence the optimal $\mathrm{pH}$ of lipase immobilised (Ye et al., 2007). The optimal $\mathrm{pH}$ for CRL immobilised onto the ground Scirpus grossus L.f. fibre using the crosslinking method at pH 7 (Charuchinda et al., 2013). 


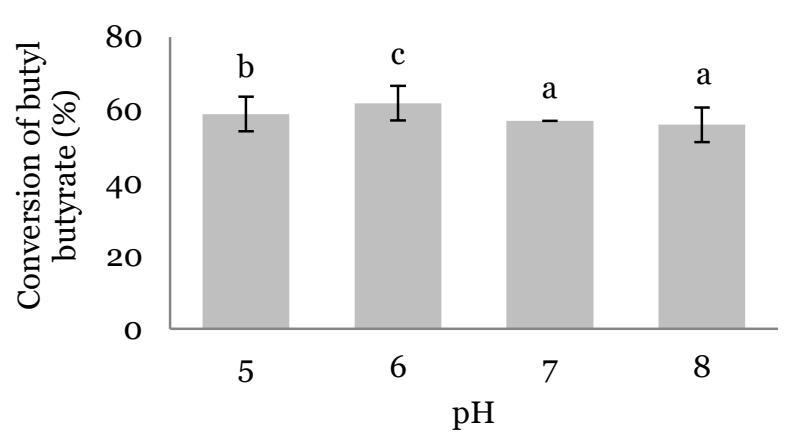

Figure 2. Esterification yield at different $\mathrm{pH}$ buffer solution *Data expressed as mean of duplicate \pm error value

*a, b, c, subsets in Tukey HSD test for alpha = 0.05

\section{Effect of eggshells particle size}

Eggshells in the size of $\leq 1 \mathrm{~mm}, 1-2 \mathrm{~mm}$ and $2-4 \mathrm{~mm}$ were immobilised at the conditions of $30^{\circ} \mathrm{C}, \quad 0.75 \%$ of glutaraldehyde concentration and kept in incubator shaker for $3 \mathrm{hr}$ at $\mathrm{pH}$ 7. The size of the eggshells has a significant effect on esterification yield of the immobilised CRL (Figure $3)$. The smallest size of the eggshells $(\leq 1 \mathrm{~mm})$ gives the highest esterification yield, which is $65.18 \%$. There is $57.04 \%$ of yield by using eggshells with the size of 1-2mm and $56.67 \%$ for the size of $2-4 \mathrm{~mm}$. The fact that the smaller size eggshell has a bigger surface area may improve the efficiency of the immobilised lipase by allowing more lipases to be attached (Jia et al., 2003).

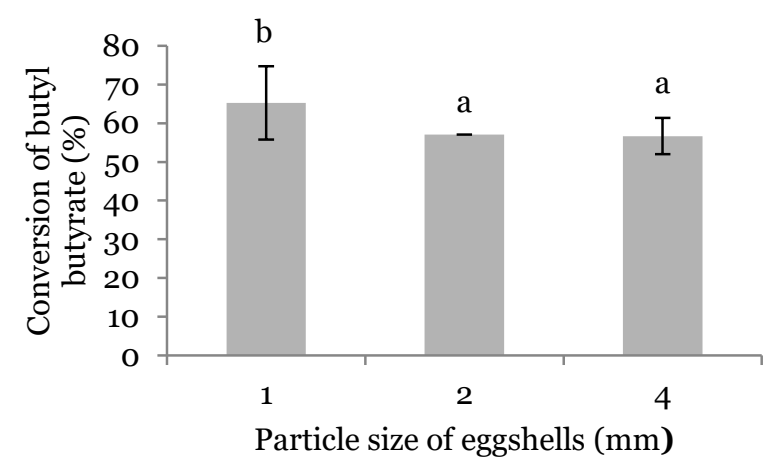

Figure 3. Esterification yield at a different particle size of eggshells

*Data expressed as mean of duplicate \pm standard deviation *a, b, subsets in Tukey HSD test for alpha $=0.05$

\section{Effect of immobilisation time}

The aliquots of the reaction mixture were analysed after esterification using the immobilised CRL prepared at different immobilisation time (1-4 hr). The result (Figure 4) indicates that the immobilisation time is a significant factor influencing the esterification yield. The ester yield has increased from $60.74 \%$ to $64.07 \%$ during 1 to $3 \mathrm{hr}$. It reaches the maximum conversion (64.07\%) when immobilisation is carried out for $3 \mathrm{hr}$. The lowest conversion of butyl butyrate (60.74\%) is obtained as the cross-linked time is the shortest ( $1 \mathrm{hr}$ ). With further immobilisation time (4 hr), the esterification yield decreases to $57.04 \%$. The denaturation of the lipase protein may occur due to excessive cross-linking that changes the configuration of the immobilised lipase (Babaei et al., 2014). The longer the immobilisation time, the more lipase will be immobilised, which makes the holes of the carrier thinner, thus reducing the active site available for substrate (Jiang et al., 2005).

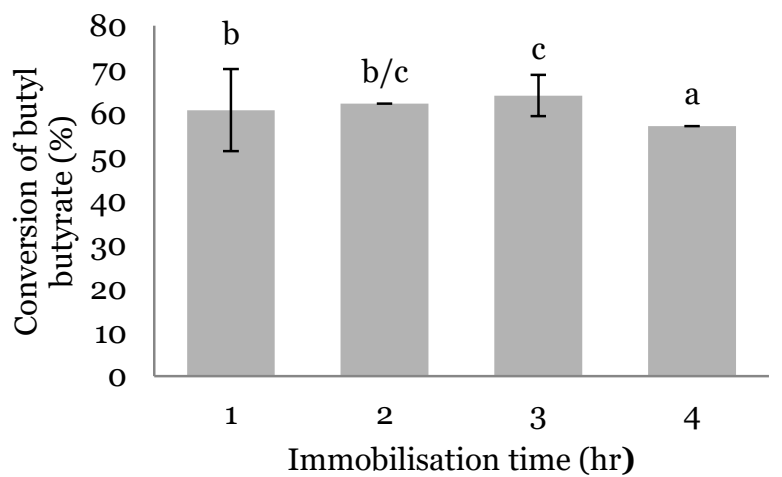

Figure 4. Esterification yield at different immobilisation time

*Data expressed as mean of duplicate \pm error value *a, b, c, subsets in Tukey HSD test for alpha $=0.05$

\section{Effect of glutaraldehyde concentration}

The concentration of glutaraldehyde shows that it is statistically significant towards increasing the yield of esterification. Based on Figure 5, a further increase in concentration glutaraldehyde from $0.30 \%$ to $3.00 \%$ will simultaneously increase the esterification yield. The highest esterification yield is $62.96 \%$, with $0.75 \%$ of the glutaraldehyde concentration solution. Eventually, as the glutaraldehyde solution continuously increases, the yield 
gradually decreases. Lipase requires adequate glutaraldehyde concentration to hold them stable on the eggshells. Therefore, the absolute concentration of glutaraldehyde solution will be able to improve the ester synthesis (Charuchinda et al., 2013).

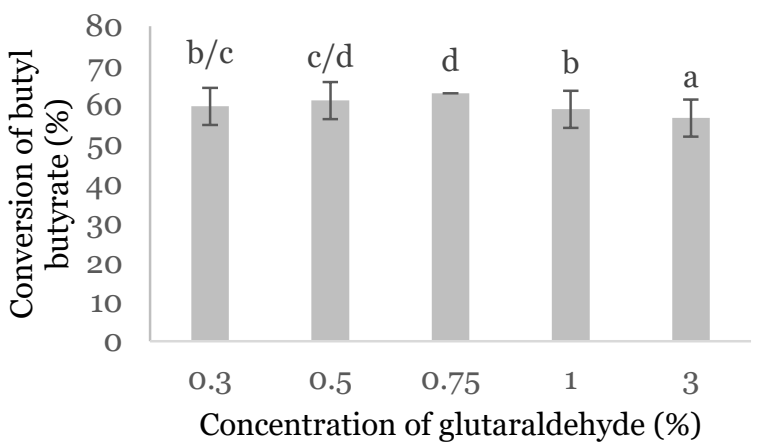

Figure 5. Esterification yield at different concentration of glutaraldehyde

*Data expressed as mean of duplicate \pm standard deviation

*a, b, c, d subsets in Tukey HSD test for alpha $=0.05$

\section{B. Study on Different Parameter for the Esterification Reaction}

\section{Effect of reaction time}

The reaction time is significance to the yield of esterification. The ester synthesis increases gradually from $1 \mathrm{hr}$ to $4 \mathrm{hr}$ (Figure 6). Adequate reaction time is required for the immobilised lipase to react with the substrate until all the active site of the immobilised lipase was saturated. The highest esterification yield is obtained after $4 \mathrm{hr}$ of reaction time $(71.48 \%)$. Nonetheless, the reaction time at $3 \mathrm{hr}$ is chosen as the best esterification time because of economic reasons and the yield is not significantly different from the maximum yield. This reaction time is faster compared to the findings in Ozylmaz and Grezer (2010), in which CRL is immobilised onto calcium alginate gel to produce isoamyl acetate, ethyl valerate and butyl acetate that reach maximum yield after $10 \mathrm{hr}$ of reaction time.

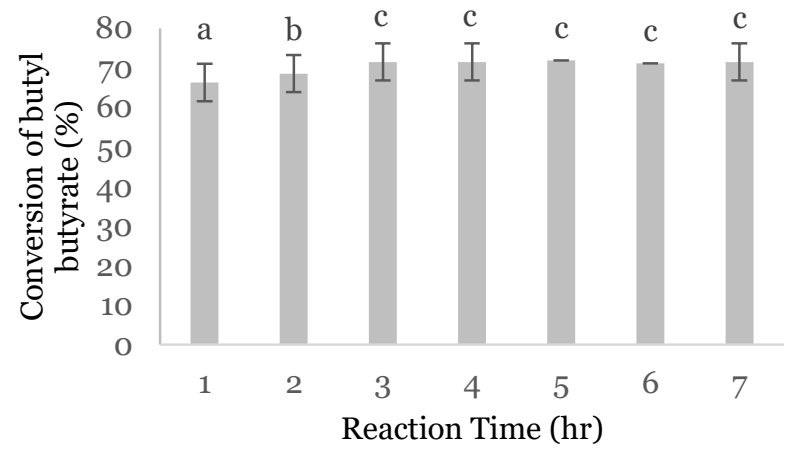

Figure 6. Esterification yield at different reaction time *Data expressed as mean of duplicate \pm standard deviation *a, b, c subsets in Tukey HSD test for alpha = 0.05

\section{Effect of temperature}

The variation of the incubation temperatures shows a significant effect on the yield of butyl butyrate after $3 \mathrm{hr}$ of reaction (Figure 7). The optimum temperature for the esterification of butyl butyrate is at $30^{\circ} \mathrm{C}(67.04 \%)$. The esterification yield gradually decreases as the temperature increases to $60^{\circ} \mathrm{C}$ with minimum butyl butyrate yield (46.30\%). The high temperature leads to the denaturation of the lipase by breaking the bond that maintains the active site of the enzyme (Sasi et al., 2006).

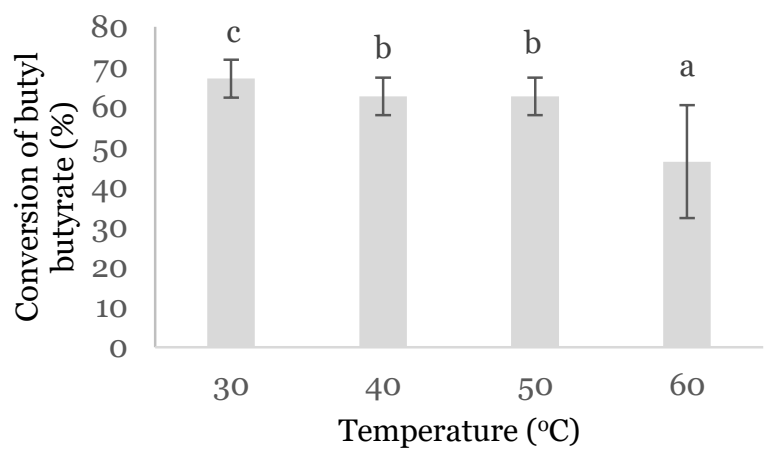

Figure 7. Esterification yield at different esterification temperature.

*Data expressed as mean of duplicate \pm standard deviation

*a, b, c subsets in Tukey HSD test for alpha $=0.05$

\section{Effect of substrate molar ratio}

The result shown in Figure 8 indicates that the molar ratio of the substrate is a significant factor towards butyl butyrate conversion. The ester synthesis gradually decreases from $86.8 \%$ to $58.99 \%$ when the molar ratio of the substrate 
increases from 0.2 to 1.8 . Theoretically, the reaction increases dramatically when the substrate concentration increases until the active site of the enzyme becomes saturated. In contrast, the esterification reaction yield does not increase, although more substrate is added. Furthermore, excess water produced from the esterification reaction will facilitate hydrolysis reaction where the ester product will be reversely converted to the substrate. (Divaka and Monohar, 2007).

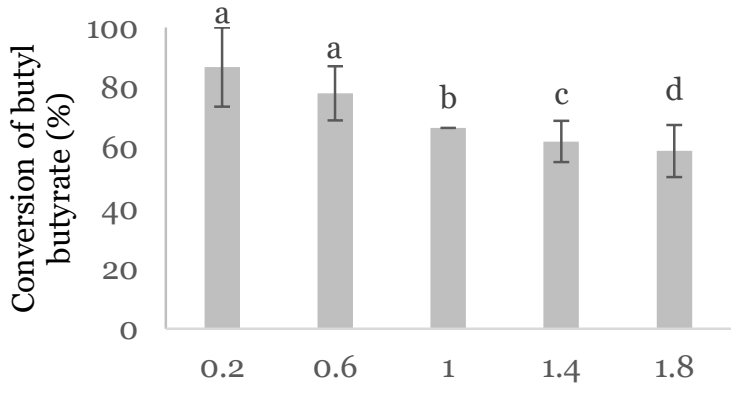

Substrate molar ratio (butyric acid:Butanol)

Figure 8. Esterification yield at a different molar ratio of substrate

*Data expressed as mean of duplicate \pm standard deviation *a, b, c, d subsets in Tukey HSD test for alpha $=0.05$

\section{Effect of immobilised lipase loading}

The result for different immobilised lipase loading is a significant factor towards ester formation, as shown in Figure 9. The higher the amount of lipase loading (0.1-2.og), the higher the yield of esterification. The lowest yield (38.89\%) is obtained when $0.1 \mathrm{~g}$ of immobilised lipase limits the complete reaction of all the substrate within the specified reaction time (Aziz et al., 2016). There is no significant difference in the catalytic activity of the lipase beyond 2.og of the lipase loading. This could be due to enzyme aggregation that reduces the efficiency of the immobilised lipase. Foresti and Ferreira (2005) reported that agglomeration using immobilised lipase in a solventfree system leads to aggregate formation. The $2 \mathrm{~g}$ of immobilised lipase loading has been chosen as the maximum catalyst loading for esterification to prevent the waste of excess lipase as lipases are very costly.

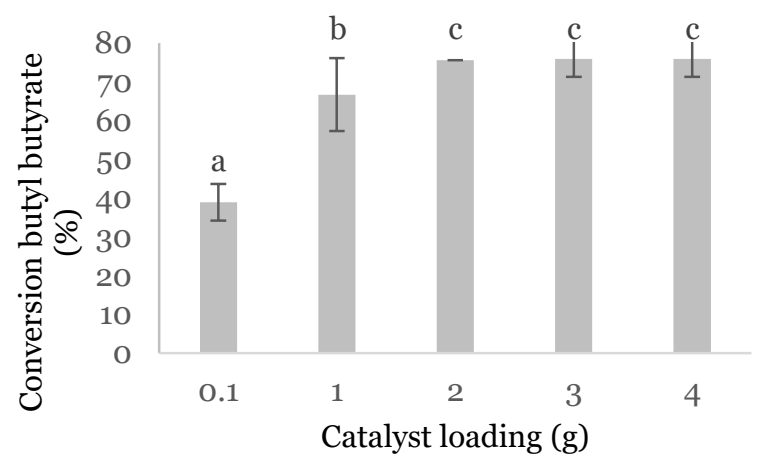

Figure 9. Esterification yield at different immobilised lipase loading

*Data expressed as mean of duplicate \pm standard deviation *a, b, c, d subsets in Tukey HSD test for alpha $=0.05$

\section{Experimental Validation using Optimum Conditions}

Based on a single parameter study, the optimal immobilisation conditions (0.75\%, v/v glutaraldehyde concentration, $5^{\circ} \mathrm{C}, 3 \mathrm{hr}, \mathrm{pH} 6$ buffer solution and $\leq 1 \mathrm{~mm}$ ) were adopted for the esterification reaction. The optimum conditions for the esterification reaction were carried out using $2 \mathrm{~g}$ of the immobilised eggshells loading at $30^{\circ} \mathrm{C}$ with 0.2 molar ratio of substrates (butyric acid:n-butanol) for 3 $\mathrm{hr}$ incubation period. The maximum yield of butyl butyrate obtained was $93.33 \%$.

\section{Reusability of Immobilised Lipase}

Based on Figure 10, the immobilised CRL on eggshells exhibits excellent reusability. The immobilised CRL on the eggshells is able to maintain $93.33 \%$ of the esterification yield for 21 cycles. The esterification yield shows sign of reduction of $52.22 \%$ at the $31^{\text {st }}$ cycle. Repeated washing of the immobilised CRL after the esterification will cause the immobilised lipase washed off (Silva et al., 2013). Based on a study by Spinelli et al. (2014), the CRL immobilised onto the modified Eupergit $\AA C$ (copolymer of methacrylamide) still maintain $60 \%$ of its activity after being reutilised for 8 times. This proves that CRL forms a more stable, effective and stronger chemical bond with the eggshells. The increased repeatable usage of immobilised lipase for a longer time will enable it to reduce the price of the product (Ranganathan et al., 2008). 


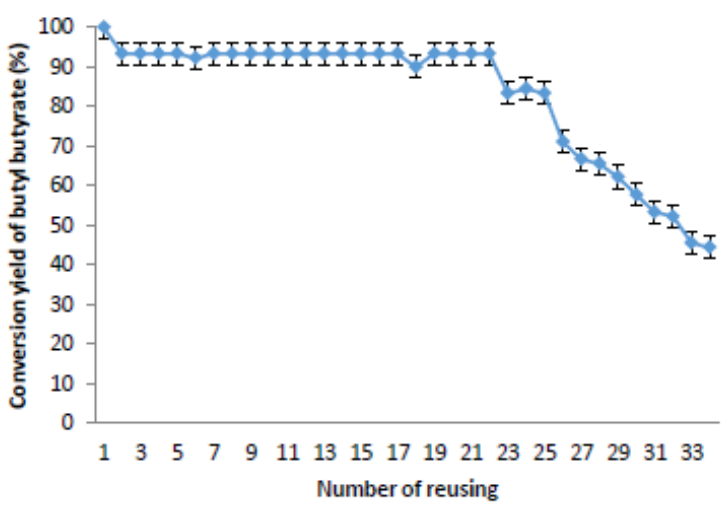

Figure 10. Reusability of immobilised lipase on eggshells

\section{E. Scanning Electron Microscopy (SEM) Analysis}

Based on Figure 11(a), a significant number of pores can be observed on the outer surface of the eggshells. An eggshell is porous with a semi-permeable membrane. Normally, an eggshell is covered by 6,000 to 17,000 pores (Khanna and Yadav, 2005). Most of the pore sizes of the chicken eggshells

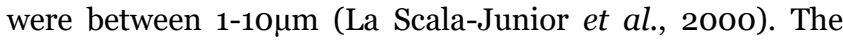
pores on the eggshells are reduced and not particularly obvious after undergoing immobilisation, as shown in Figure 11(b). The change in the surface morphology may be due to the pores being occupied by lipases. There are more cavities in the surface of the eggshells after the esterification process. The cavities may be caused by the reaction between calcium carbonate in the eggshells and butyric acid, which is a substrate of esterification. About $94 \%$ of the eggshell comprises of calcium carbonate (Stadelman, 2000).

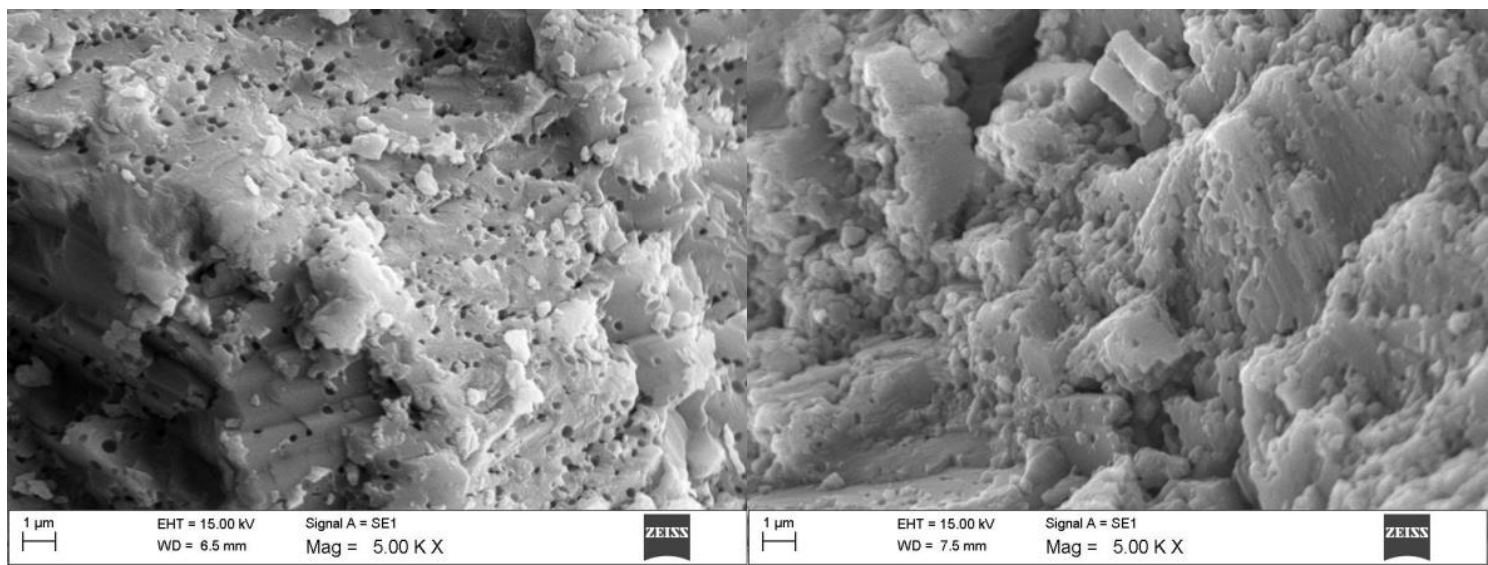

(a)

(b)

Figure 11. Eggshells surface before immobilization (a); eggshells surface after immobilization (b), under scanning electron microscope at 5000 magnifications.

\section{CONCLUSIONS}

The best immobilisation condition to immobilise lipase on eggshells through cross-linking were at $50^{\circ} \mathrm{C}$, with a buffer solution with $\mathrm{pH} 6, \leq 1 \mathrm{~mm}$ of the eggshell's particle size, 3 hr of immobilisation time and $0.75 \%$ of glutaraldehyde solution. The optimum conditions for the esterification obtained were $2 \mathrm{~g}$ of the immobilised CRL, $30^{\circ} \mathrm{C}, 0.2 \mathrm{M}$ ratio of substrate concentration and $3 \mathrm{hr}$ of esterification reaction. The maximum conversion yield of butyl butyrate was 93.33\%. The reusability of the immobilised lipase was also studied, and the findings indicated that $50 \%$ of its initial activity was retained after 31 times being reutilised.

\section{ACKNOWLEDGEMENTS}

This work was supported by Kementerian Pendidikan Malaysia (KPM) Transdisciplinary Research Scheme Grant (TRGS) (6711374). In addition, Nor Fauziah Mohd Zain is also credited for her contribution. 


\section{REFERENCES}

[1] Aziz, HA, Aroua, MK, Yusoff, R, Abas, NA, Idris, Z, \& Hassan, HA 2016, 'Production of palm-based esteramine through heterogeneous catalysis', Journal of Surfactants and Detergents, vol. 19, no. 1, pp.11-18.

[2] Babaei, M, Karimi, A, \& Hejazi, MA 2014, 'Use of mesoporous $\mathrm{MnO}_{2}$ as a support for immobilization of lipase from Candida rugosa', Chemical Industry \& Chemical Engineering Quarterly, vol. 20, no. 3, pp. 371-378.

[3] Bezbradica, D, Karalazic, I, Ognjanovic, N, Mijin, D, Siler-Marinkovic, S, \& Knezevic, Z 2006, 'Studies on specifity of Candida Rugosa lipase catalyzed esterification reactions in organic media', Journal of the Serbian Chemical Society, vol. 71, no. 1 , pp. 31-41.

[4] Chang, SF, Chang, SW, Yen, YH, \& Shieh, CJ 2007, 'Optimum immobilization of Candida rugosa lipase on Celite by RSM', Applied Clay Science, vol. 37, no. (1-2), pp. 67-73.

[5] Charuchinda, S, Kensingh, P, \& Chulalaksananukul, W 2013, 'Immobilization of the Candida rugosa lipase onto a Scirpus grossus L.f. fiber as biocatalyst for biodiesel synthesis via hydrolysis-esterification', African Journal of Biology, vol. 1, no. 2, pp. 61-68.

[6] Chattopadhyay, S, \& Sen, R 2012, 'A comparative performance evaluation of jute and eggshell matrices to immobilize pancreatic lipase', Process Biochemistry, vol. 47, no. 5, pp. 749-757.

[7] Divaka, S, \& Manohar, B 2007, Use of lipase in the industrial production of esters, Industrial Enzymes, pp. 283-300.

[8] Doaa, ARM, \& Wafaa, AH 2009, 'Potential application of immobilization technology in enzyme and biomass production', Journal of Applied Sciences Research, vol. 5, no. 12, pp. 2466-2476.

[9] Foresti, ML, \& Ferreira, ML 2005, 'Solvent-free ethyl oleate synthesis mediated by lipase from
Candida antarctica B adsorbed on polypropylene powder', Catalysis Today, vol. 107-108, pp. 23-30.

[10] Glatz, P, \& Zhihong, M 2009, High value products from membrane and processed eggshell membrane hatchery waste, Rural Industries Research and Development Corporation, publication no. 09/061, Australian Government.

[11] Jesionowski, T, Zadarta, J, \& Krajewska, B 2014, 'Enzyme immobilization by adsorption: a review', Adsorption, vol. 20, pp. 801-821.

[12] Jia, HF, Zhu, GY, \& Wang, P 2003, 'Catalytic behavior of enzymes attached to nanoparticles: the effect of particle mobility', Biotechnology \& Bioengineering, vol. 84, pp. 406-414.

[13] Jiang, D, Long, S, Huang, J, Xiao, H, \& Zhou, J 2005, 'Immobilization of Pycnoporus sanguineus laccase on magnetic chitosan microspheres', Biochemical Engineering Journal, vol. 25, no. 1, pp. $15-23$.

[14] Khanna, DR, \& Yadav, PR 2005, Biology of Birds, Discovery Publishing House, pp. 99-101, New Delhi, India.

[15] La Scala, JrN, Boleli, IC, Ribeiro, LT, Freitas, D, \& Macari, M 2000, 'Pore size distribution in chicken eggs as determined by mercury porosimetry', Revista Brasileira de Ciência Avícola, vol. 2, no. 2, pp. $177-180$.

[16] Lee, R 2011, Malaysians consume 20 million eggs daily - with 15\% left to spare, The Star, viewed 6 June 2018 http://www.thestar.com.my/news/nation/2011/10 /15/malaysians-consume-20-million-eggs-daily-with-15-left-to-spare/.

[17] Makkar, HPS, \& Sharma, OP 1983, 'Eggshells as a carrier for enzyme immobilization', Biotechnology and Bioengineering, vol. XXV, pp. 592-597.

[18] Martins, AB, Friedrich, JLR, Cavalheiro, JC, Garcia-Galan, C, Barbosa, O, Ayub, Marco, AZ, Fernandez-Lafuente, R, Rodrigues, RC 2013a, 'Improved production of butyl butyrate with lipase 
from Thermomyces lanuginosus immobilized on styrene-divinylbenzene beads', Bioresource Technology, vol. 134, pp. 417-422.

[19] Martins, AB, Friedrich, JLR, Rodrigues, RC, Garcia-Galan, C, Fernandez-Lafuente, R, \& Ayub Marco AZ 2013b, 'Optimized butyl butyrate synthesis catalyzed by Thermomyces lanuginosus lipase', Biotechnology Progress, vol. 29, no. 6, pp.1416-1421.

[20] Mohamad, NR, Marzuki, NHC, Buang, NA, Huyop, F, Wahab, RA 2015, 'An overview of technologies for immobilization of enzymes and surface analysis technique for immobilized enzymes', Biotechnology, Biotechnological Equipment, vol. 29, no. 2, pp. 205-220.

[21] Nasratun, M, Said, HA, Noraziah, A, \& Abd Alla, AN 2009, 'Immobilization of lipase from lipase from Candida rugosa on chitosan beads for transesterification reaction', American Journal of Applied Science, vol. 6, no. 9, pp. 1653-1657.

[22] Ozylimaz, G, \& Gezer, E 2010, 'Production of aroma esters by immobilized Candida rugosa and porcine pancreatic lipase into calcium alginate gel', Journal of Molecular Catalysis B: Enzymatic, vol. 64, pp. 140-145.

[23] Pandey, A, Benjamin, S, Soccol, CR, Nigam, P, Krieger, N, \& Soccol, VT 1999, The realm of microbial lipases in biotechnology, Biotechnology and Applied Biochemistry, pp.119-31.

[24] Ranganathan, SV, Narasimhan, SJ, \& Muthukumar, K 2008, 'An overview of enzymatic production of biodiesel', Bioresource Technology, vol. 99, pp. 3975-3981.

[25] Santos, JC, \& de Castro, HF 2006, 'Optimization of lipase-catalysed synthesis of butyl butyrate using a factorial design', World Journal of Microbiology \& Biotechnology, vol. 22, pp.1007-1011

[26] Sasi, P, Mehrota, RR, \& Debnath, M 2006, 'Esterification reactions catalysed by surfactantcoated Rhizopus arrhizus lipase', Indian Journal of Biotechnology, vol. 5, pp. 364-367.

[27] Silva, ALP, Nascimento, RG, Arakaki, LNH, Arakaki, T, Espinola, JGP, \& Fonseca, MG 2013,
'Organofunctionalized silica gel as a support for lipase', Journal of non-crystalline solids, vol. 376, pp. 139-144.

[28] Spinelli, D, Coppi, S, Basosi, R, \& Pogni, R 2014, 'Biosynthesis of ethyl butyrate with immobilized Candida rugosa lipase onto modified Eupergit ${ }^{\circ}$, Biocatalysis, vol. 1, no. 1, pp.1-12.

[29] Saponjic, S, Knezevic-Jugovic, ZD, Bezbradica, DI, Zuza, MG, Saied, OA, Boskovic-Vragolovic, N, \& Mijin, DZ 2010, 'Use of Candida rugosa immobilized on sepabeads for the amyl caprylate synthesis: Batch and fludized bed reactor study', Electronic journal of Biotechnology, vol. 13, no. 6, pp. 1-15.

[30] Stadelman, WJ 2000, Eggs and egg products, Encyclopedia of Food Science and Technology, Second edition John Wiley Sons, New York, pp.593-599.

[31] Ting, WJ, Tung, KY, Giridhar, R, \& Wu, WT 2006, 'Application of binary Immobilized Candida rugosa lipase for hydrolysis of soybean oil', Journal of Molecular Catalysis B: Enzymatic, vol. 42, no. (12), pp.32-38.

[32] Vemuri, G, Banerjee, R, Bhattacharyya, BC 1998, 'Immobilization of lipase using eggshells and alginate as carriers: Optimization of reaction conditions', Bioprocess Engineering, vol. 19, no. 2, pp. 111-114.

[33] Wu, C, Zhou, G, Jiang, X, Ma, J, Zhang, H, Song, H 2012, 'Active biocatalyst based on Candida rugosa lipase immobilized in vesicular silica', Process Biochemistry, vol. 47, pp. 953-959.

[34] Wu, S, Tshou, H, Hsu, H, Hsu, S, Liou, S, Ho, W 2013, 'A hydrothermal synthesis of eggshell and fruit waste extract to produce nanosized hydroxypatite', Ceramics International, vol. 39, no. 7, pp.8183-8188.

[35] Yahya, ARM, Anderson, WA, \& Moo-Young, M 1998, 'Ester synthesis in lipase catalyzed reactions', Enzyme and Microbial Technology, vol. 23, no. (78), pp. 438-450.

[36] Ye, P, Jiang, J, \& Xu, ZK 2007, 'Adsorption and activity of lipase from Candida rugosa on the 
chitosan-modified poly(acrylonitrile-co-maleic

acid) membrane surface', Colloids and Surfaces $B$,

vol. 6o, no. 1, pp. 62-67. 